\title{
EFFECT OF BETA-CAROTENE INJECTION ON ESTRUS, VITAMIN A AND ESTRADIOL-17ß CONCENTRATIONS IN PUBERTAL FARAFRA EWE LAMBS
}

\author{
A.A. Salem ${ }^{1}$; N. A. El-Shahawy ${ }^{2}$ and I. A. Soliman ${ }^{1}$ \\ ${ }^{1}$ Animal Production Department, Faculty of Agriculture, Assiut University, Assiut, Egypt, ${ }^{2}$ Institute of Animal \\ Production Research Center, Dokki, Giza, Egypt
}

\section{SUMMARY}

To study the effect of Beta Carotene $(B C)$ treatment on puberty and related phenomena as well as concentrations of vitamin A, and estradiol-17\% hormone 48 Farafra ewe lambs were divided into two equal groups. The control group (G1) was injected intramuscularly with $0.1 \mathrm{mg}$ arachis oil, while the treated group (G2) was injected with $0.1 \mathrm{mg} B C+$ arachis oil / $\mathrm{kg}$ twice a week from weaning to puberty. Estradiol $17 \beta$, progesterone $\left(P_{4}\right), B C$ and vitamin $A$ were assayed in blood sera taken from 6 animals/ group.

Results indicated that treatment with $B C$ was accompanied by increasing estradiol-17 $\beta$ and vitamin $A$ concentrations at puberty. Ewe lambs of $G 2$ displayed $(P<0.05)$ more estrous cases post-puberty than G1. Both groups displayed short cycles at puberty (6.2 d for G2 vs. 7.4 d for G1) with no significant difference between the two groups. $P_{4}$ concentration at estrus of puberty was $\geq 1.0 \mathrm{ng} / \mathrm{ml}$ of both groups. Post-puberty BC and Vit.A concentrations had $(P<0.05)$ positive correlation in the two studied groups. BC concentration in $G 2$ was higher $(P<0.05)$ at pre-puberty than post-puberty.

In conclusion, BC injection had an impact on number of observed estrous cases, vitamin $A$ and estradiol$17 \beta$ concentrations at puberty and post-puberty estrus, which might be applied in the animal farms to enhance estrus cases around puberty.

\section{Keywords: beta-catrotene, ewe lambs, estradiol-17ß, estrous activity, puberty, progesterone, vitamin A}

\section{INTRODUCTION}

$\mathrm{BC}$ is essential for many of the biological processes at body level as the source of vitamin A (Schweigert, 1998). Vitamin A (Vit. A) is relatively low in blood plasma of sheep, due to the poor content of $\beta$-carotene $(\mathrm{BC})$ in roughages as well as very low rate of absorption in intestine (Ross, 1999). This means that sheep should be supplemented with exogenous sources of BC to avoid deficiency of Vit. A. Inadequate nutrition in ruminants had negative effects on metabolic and hormonal profiles, puberty onset, regular estrous cycles and fertility (Scaramuzzi et al., 2006 and Meza-Herrera et al. 2007)..

Oxidative stress (OS) occurs during breeding and pregnancy especially when animals are fed poor feed stuff. Thus, reactive oxygen species (ROS) are formed as a result of many stress factors (MohebbiFani et al., 2012). OS induces lipid peroxidation, which promotes apoptosis, and causes some diseases via its effect on redox status, redox-sensitive signaling pathways and gene expression (Ames et al., 1993). Vitamin A and BC injections support the antioxidant system (Kamuloulu and Beytut , 2005) to avoid the harm effects of the free radicals (Little and Gladen, 1999). Up to the knowledge of the authors no data are available about the effect of BC treatment on age at puberty of Farafra ewe lambs.

The main purpose of this study is to study the role of exogenous BC treatment on puberty of Farafra ewe lambs with particular reference to post puberty estrous behavior, and blood concentrations of Vit.A, $\mathrm{BC}$, progesterone and estradiol-17 $\beta$.

\section{MATERIAL AND METHODS}

\section{Animals, Management and Feeding}

A total of 48 Farafra ewe lambs of four months of age and mean body weight of $13.25 \pm 0.43 \mathrm{~kg}$ were divided randomly into two equal groups $(n=24$ each). Ewe lambs of the first group (G1) were injected intra-muscularly (IM) with $0.1 \mathrm{ml} / \mathrm{kg}$ body weight arachis oil (free from $\mathrm{BC}$ and Vit. A), while ewe lambs of the second group (G2) was injected IM just after weaning with $0.1 \mathrm{mg} / \mathrm{kg}$ BC loaded on arachis oil twice a week for four months (about 8 months of age). Lambs were housed in semi-open pens and were fed according to NRC (2007) on a ration contained $14.0 \%$ crude protein, $2.0 \%$ crude fat $(2700 \mathrm{Kcal} / \mathrm{Kg}$ ration metabolizable energy, ME), $15 \%$ crude fiber, $9 \%$ ash and $12 \%$ moisture. No green forages were offered during the whole experiment. Water was available all the day time throughout the experimental period.

\section{Estrous Detection}

Prior to the expected time of puberty (The $8^{\text {th }}$ month of age) two fertile rams were allowed to run with the ewe lambs for $30 \mathrm{~min}$ (15 min for each ram) daily at 8:00 am to detect the ewes in heat. Behavioral signs of estrus (e.g. vaginal mucous discharge, vulva swelling, tail twitching) as well as observation of arborization (Fern-like pattern) in a smear made from vaginal secretion have been taken into consideration as a tool to estrous detection (Salem et al., 2013). Estrous cycle length was classified as normal $14-19$, short $<14$ and long cycle 
$>19$ day. Silent estrus was determined by concentration of progesterone.

\section{Blood Collection}

Blood samples $(10 \mathrm{ml} /$ animal $)$ were withdrawn via jugular vein (JV) at 8:00 a.m. before feeding from 6 animals/group chosen randomly. Blood samples were taken from each animal twice a week before the expected puberty by one month to post-puberty by 49 d. Samples were left in the refrigerator $\left(5^{\circ} \mathrm{C}\right)$ overnight until clotting before centrifuging at $3000 \times \mathrm{g}$ for $10 \mathrm{~min}$ for harvesting blood sera. Blood sera were stored at $-20{ }^{\circ} \mathrm{C}$ until analyses.

\section{Determination of Progesterone and Estradiol-17ß Concentrations}

Progesterone $\left(\mathrm{P}_{4}\right)$ and Estradiol $17 \beta \quad\left(\mathrm{E}_{2}\right)$ concentrations were assessed using enzyme immunoassay kits (BioCheck, Inc, 323 Vintage Park drive, Foster City, CA 9404, USA). Standard curves were plotted as described by manufacturer. The minimum detectable concentrations of the progesterone and estradiol-17beta ELISA were $0.0625 \mathrm{ng} / \mathrm{ml}$ and $10 \mathrm{pg} / \mathrm{ml}$. Cross reactivity with other steroids was reported by manufacturer to be $<$ $1 \%$.

\section{BC and Vit.A assay}

Both BC and Vit.A were assayed by Colormetric method (Suzuki and Katoh, 1990). Reagents used for $\mathrm{BC}$ (dye $0.2 \mathrm{mmol} / \mathrm{L}$, buffer $1.0 \mathrm{~mol} / \mathrm{L}$ and distilled water) and Vit. A (2, 6-dichlorophenol-indophenol, buffer and distilled water) analyses were purchased from ABC Diagnostic-Egypt.

\section{Statistical Analysis}

Data were analyzed using SPSS (2007). Data were presented as number, percentage, mean and standard error. Chi-square test was used to compare qualitative variables between treated and control groups. Mann-Whitney test was used to compare qualitative variables between treated and control groups. P-value was considered significant when reached $\leq \mathrm{P}<0.05$.

\section{RESULTS}

1. Concentrations of Beta-carotene (BC) and vitamin $A$ around puberty

Based on the concentrations of $\mathrm{P}_{4}$ concentration as well as the appearance of fern-like shape of vaginal mucous smears, day of the first estrus (puberty) was determined. Age of puberty in G1 and G2 was differed non-significantly being $269.2 \pm 5.9$ and $264.8 \pm 8.4$ day, respectively. Concentrations of $\mathrm{BC}$ and Vitamin A at puberty, estrus and met-estrus phases were higher $(\mathrm{P}<0.05)$ inG2 than $\mathrm{G} 1$ by more than $50 \%$ (Table 1).

\section{Effect of BC on post - puberty estrous cycle aspects}

Estrous cycles just follow puberty were short in length in both studied groups. Overall mean of estrous cycle cases differed non-significantly between G1 and G2. However, it is worth to underline that the detected number of estrous cycles 69 post puberty was almost double in G2 compared to G1 (Table 2 ).

3. BC and Vit A concentrations at puberty and pre-and post-puberty

Concentrations of $\mathrm{BC}$ and Vit. A around puberty had no consistent trend. However, BC at puberty was higher $(\mathrm{P}<0.05)$ in $\mathrm{G} 2$ than $\mathrm{G} 1$ and similar trend was observed 25 and $21 \mathrm{~d}$ prior to puberty and days 21 , 25, 38 and 42 post -puberty, the difference in concentrations in other days was not significant, as the trend of Vit. during the three phases studied around puberty (Table 3 ).

\section{Effect of Beta-carotene treatment on estradiol- $17 \beta$ concentrations}

$\mathrm{E}_{2}$ concentrations in $\mathrm{G} 2$ at puberty and estrous and met-estrous phases post-puberty was higher $(\mathrm{P}<0.05)$ compared to $\mathrm{G} 1$ (Fig.1).

Table 1. Concentrations (mean $\pm \mathrm{SE})$ of $\mathrm{BC}(\mathrm{mmol} / \mathrm{L})$ and Vit.A (mg/L) during puberty, estrus and metestrous phases of Beta-Carotene (G2) and Control (G1) treated groups

\begin{tabular}{lcc}
\hline Trait & $\mathrm{G} 2$ & $\mathrm{G} 1$ \\
\hline Beta-carotene concentrations & $0.85 \pm 0.04^{*}$ & $0.38 \pm 0.04$ \\
At puberty & $0.91 \pm 0.05^{*}$ & $0.42 \pm 0.03$ \\
At estrous phase post- puberty & $0.80 \pm 0.11^{*}$ & $0.38 \pm 0.06$ \\
At met-estrus phase post- puberty & & \\
Vitamin A concentrations & $703.83 \pm 129.83^{*}$ & $146.93 \pm 19.02$ \\
At puberty & $635.50 \pm 60.89^{*}$ & $237.62 \pm 29.51$ \\
At estrous phase post-puberty & $545.20 \pm 130.18^{*}$ & $248.58 \pm 31.97$ \\
At met-estrous phase post-puberty & &
\end{tabular}


Table 2. Effect (mean \pm SE) of treatment of Beta-carotene (G2) on post-puberty estrous cycle aspects compared with the control group (G1)

\begin{tabular}{lcc}
\hline Traits & G2 & G1 \\
\hline Number of estruses during 69 d post- puberty & $17 *$ & 9 \\
Length of First short estrous cycle (d) & $6.20 \pm 1.74$ & $7.40 \pm 1.97$ \\
Overall lengths of estrous cycles during 69 d & $13.23 \pm .81$ & $15.67 \pm 1.62$ \\
Length of regular estrous cycle (d) & $16.83 \pm .19$ & $19.60 \pm 5.68$ \\
\hline
\end{tabular}
$=\mathrm{P}<0.5$

Table 3. Concentrations (mean $\pm \mathrm{SE}$ ) of vitamin $\mathrm{A}$ and Beta-carotene as measured at different stages around puberty as affected by treatment with beta-carotene (G2) and control (G1)

\begin{tabular}{|c|c|c|c|c|c|}
\hline \multirow{2}{*}{$\begin{array}{l}\text { Stage around } \\
\text { puberty }\end{array}$} & \multirow{2}{*}{ 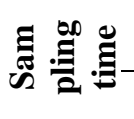 } & \multicolumn{2}{|c|}{ Vit. A concentrations (mg/L) } & \multicolumn{2}{|c|}{ BC concentrations $(\mathrm{mmol} / \mathrm{L})$} \\
\hline & & G2 & G1 & G2 & G1 \\
\hline \multirow[t]{6}{*}{ Pre-puberty } & 25 & $512.5 \pm 102.0^{*}$ & $201.6 \pm 50.3$ & $0.92 \pm 0.05^{*}$ & $0.39 \pm 0.06$ \\
\hline & 21 & $777.0 \pm 2.0 *$ & $287.0 \pm 82.9$ & $1.03 \pm 0.01 *$ & $0.52 \pm 0.05$ \\
\hline & 17 & $574.0 \pm 164.0$ & $365.6 \pm 45.9$ & $0.70 \pm 0.23$ & $0.45 \pm 0.08$ \\
\hline & 14 & $567.0 \pm 177.0$ & $240.9 \pm 76.9$ & $0.72 \pm 0.19$ & $0.36 \pm 0.03$ \\
\hline & 7 & $789.3 \pm 358.8$ & $175.8 \pm 8.8$ & $0.75 \pm 0.20$ & $0.38 \pm 0.03$ \\
\hline & 3 & $594.5 \pm 287.0$ & $179.4 \pm 26.3$ & $0.77 \pm 0.15$ & $0.41 \pm 0.10$ \\
\hline \multirow[t]{4}{*}{ Puberty } & 0 & $703.8 \pm 129.8^{*}$ & $146.9 \pm 19.0$ & $0.85 \pm 0.04)^{*}$ & $0.38 \pm 0.04$ \\
\hline & 3 & $471.5 \pm 96.9$ & $225.5 \pm 51.3$ & $0.79 \pm 0.04 *$ & $0.42 \pm 0.03$ \\
\hline & 11 & $230.5 \pm 66.5$ & $161.0 \pm 16.0$ & $0.94 \pm 0.13 *$ & $0.38 \pm 0.06$ \\
\hline & 14 & $563.8 \pm 174.3$ & $201.0 \pm 54.0$ & $0.94 \pm 0.11 *$ & $0.39 \pm 0.02$ \\
\hline \multirow[t]{9}{*}{ Post puberty } & 17 & $532.8 \pm 307.3$ & $210.5 \pm 25.5$ & $0.92 \pm 0.06^{*}$ & $0.39 \pm 0.04$ \\
\hline & 21 & $625.3 \pm 51.3 *$ & $276.0 \pm 12.0$ & $0.78 \pm 0.02 *$ & $0.38 \pm 0.04$ \\
\hline & 25 & $492.3 \pm 39.8^{*}$ & $178.8 \pm 5.8$ & $0.40 \pm 0.03$ & $0.49 \pm 0.06$ \\
\hline & 28 & $478.5 \pm 7.0^{*}$ & $167.4 \pm 14.9$ & $0.44 \pm 0.03 *$ & $0.32 \pm 0.01$ \\
\hline & 35 & $269.8 \pm 3.3$ & $129.8 \pm 62.2$ & $0.80 \pm 0.01 *$ & $0.37 \pm 0.07$ \\
\hline & 38 & $579.5 \pm 35.5$ & $157.2 \pm 21.3$ & $0.91 \pm 0.03 *$ & $0.38 \pm 0.02$ \\
\hline & 42 & $713.5 \pm 65.5^{*}$ & $283.6 \pm 12.3$ & $0.95 \pm 0.04 *$ & $0.41 \pm 0.05$ \\
\hline & 45 & $425.3 \pm 199.8$ & $307.5 \pm 0.0$ & $1.05 \pm 0.11^{*}$ & $0.41 \pm 0.03$ \\
\hline & 49 & $378.5 \pm 50.5$ & $307.5 \pm 20.5$ & $0.69 \pm 0.09$ & $0.50 \pm 0.01$ \\
\hline
\end{tabular}

$=\mathrm{P}<0.5$

\section{DISCUSSION}

The no effect of $\mathrm{BC}$ treatment on age at puberty is in harmony with the finding of Huffman et al. (1987) reporting no positive effect on onset of puberty in female goat treated with BC. Meanwhile, the present findings are in contrary with the results of Arellano-Rodriguez et al. (2007) and Kawashima et al. (2009) who reported that Vit.A deficiency in farm animals delayed puberty. This difference is most probably attributed to the genotype and to the ability of animal in converting beta-carotene to vitamin A.

The obtained results revealed that experimental animals exhibited short estrous cycles at puberty agrees with findings of Parish (2010). The present of the effect of $\mathrm{BC}$ on $\mathrm{E}_{2}$ concentrations during estrous cycle phases are in harmony with findings of Haliloglu et al. (2002); Arellano-Rodriguez et al.
(2009) and Kawashima et al. (2010) where they reported that $\mathrm{BC}$ had a major role in the ovarian steroidgenesis and reproduction of many species.

Hence, level of estradiol-17 $\beta$ observed in this study may be due to the influence of $\mathrm{BC}$, which positively affected ovarian activity in goats (ArellanoRodriguez et al., 2007 and 2009).

Inconsistent trends of $\mathrm{BC}$ and Vit. A; obtained in this study; around puberty could not be explained. The most probably interpretation is the cessation of treatment before puberty, hence the observed difference is referred to the individual physiological condition.

It could be concluded from this study that BC injection may improve the estrous cyclicity of Frafra lamb ewes. 


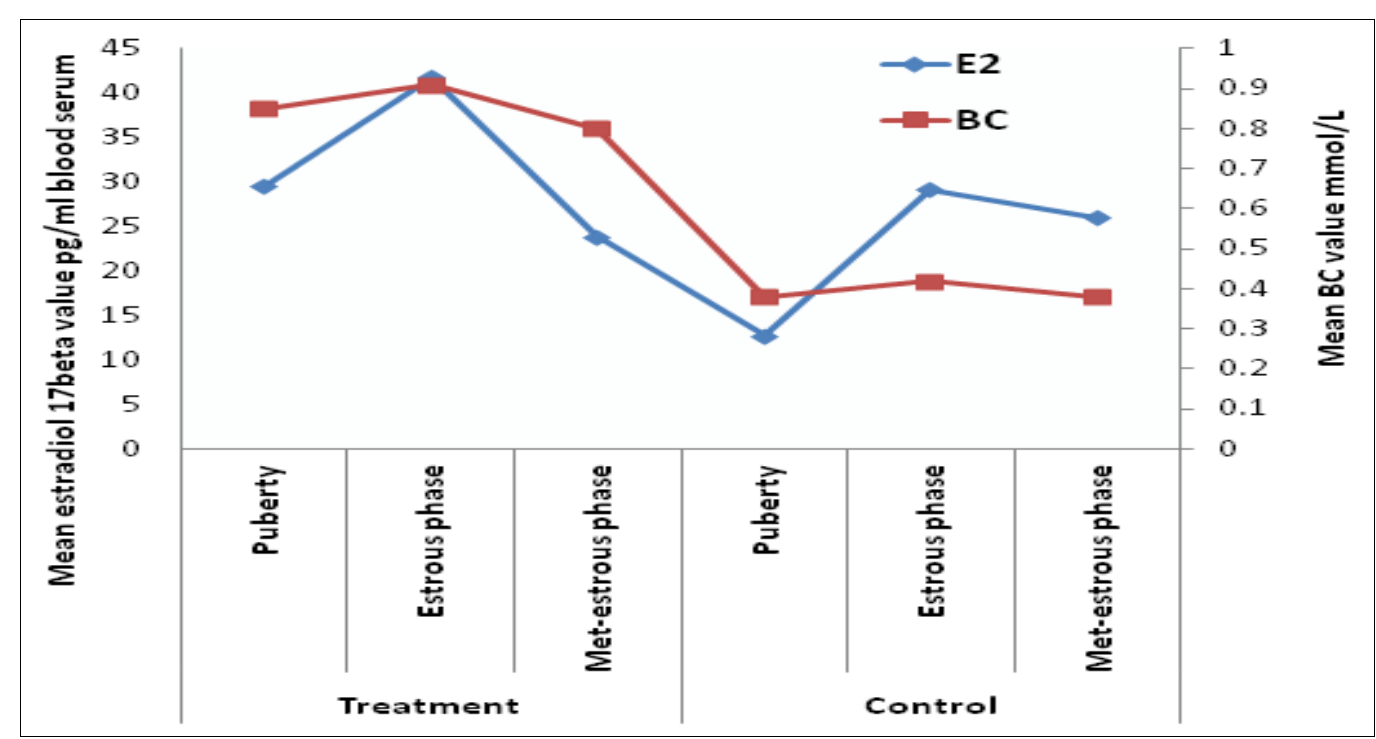

Fig. 1. Representation of $\mathrm{BC}$ and estradiol $17 \beta$ concentrations at puberty, estrus and met-estrous phases after onset of puberty in the ewe lambs injected by $\mathrm{BC}$ compared with the controls

\section{ACKNOWLEDGMENT}

Author and co-author would like to provide their thanks to laboratories of Biochemistry and Biotechnology and Molecular Unit of Assiut University for analyses BC, Vit.A, estradiol17-beta and progesterone.

\section{REFERENCES}

Ames B. N, M. K. Shigenaga and T. M. Hagen, 1993. Oxidants, antioxidants, and the degenerative diseases of aging. Proceedings of the National Academy of Sciences USA. 90: 7915-7922.

Arellano-Rodriguez G., C. A. Meza-Herrera, R. Rodriguez-Martinez, R Dionisio-Tapia, D.M. Hallford, M. Mellado and A. GonzalezBulnes, 2009. Short-term intake of b-carotenesupplemented diets enhances ovarian function and progesterone synthesis in goats. Journal of Animal Physiology and Animal Nutrition 93:710-715.

Arellano-Rodriguez G., C. A. Meza-Herrera, R. Rodriguez-Martinez, G. Velazquez-Mendez, M. Mellado, H. Salinas, M. A. Perez-Razo and F. Sanchez, 2007. Short-term betacarotene supplementation positively affects ovarian follicular development and ovulation rate in goats. Journal of Applied Animal Research. 32:177-180.

Haliloglu S., N. Baspinar, B. Serpek, H. Erdem and Bulut Z., 2002. Vitamin A and beta-carotene levels in plasma, corpus luteum and follicular fluid of cyclic and pregnant cattle. Domestic Animal Reproduction 37: 96-99

Huffman L. J., E. K. Inskeep and R. L. Goodman, 1987. Changes in episodic luteinizing hormone secretion leading to puberty in the lamb. Biology of Reproduction. 37: 755-761.
Kamuolou N.N. and E. Beytut, 2005. Effects of Vitamin A and beta-Carotene Injection on Levels of Vitamin $\mathrm{E}$ and on Glutathione Peroxidase Activity in Pregnant Tuj Sheep. Turkish Journal of Veterinary and Animal Sciences 29: 1033-1038

Kawashima C., K. Kida, F. J. Schweigert and Miyamoto A, 2009. Relationship between plasma beta carotene concentrations during the peripartum period and ovulation in the first follicular wave postpartum in dairy cows. Animal Reproduction Science 111:105-111

Kawashima C., S. Nagashima, K. Sawada, F. J. Schweigert, A. Miyamoto and K. Kida, 2010. Effect of B-carotene supply during close-up dry period on the onset of first postpartum luteal activity in dairy cows. Reproduction in Domestic Animals 45:e282-e287.

Little, R.E. and B.C Gladen,.1999. Levels of lipid peroxides in uncomplicated pregnancy: a review of the literature. Reproductive Toxicology 13: 347-352.

Meza-Herrera C. A., T. Ross, D. M. Hallford, D. Hawkins and A. Gonzalez-Bulnes, 2007, Effects of body condition and protein supplementation on LH secretion and luteal function in sheep. Reproduction In Domestic Animals 42:461-465.

Mohebbi-Fani, M., A. Mirzaei, S. Nazif, and Z. Shabbooie. 2012. Changes of vitamins A, E, and $\mathrm{C}$ and lipid peroxidation status of breeding and pregnant sheep during dry seasons on medium-to-low quality forages. Tropical Animal Health and Production 44: 259-265

NRC, 2007. Nutrient requirements of small ruminants. From the National research council. 
Parish J. A., 2010. Reproductive management of beef cattle herds (pp. 1-5). Extension Service. Mississippi State University.

Ross, A.C., 1999. Vitamin A. In: M. Shils, J. Olson, S. Moshe and A.C. Ross (eds.) Modern Nutrition in Health and Disease. Williams \& Wilkins, Baltimore, 305-313

Salem A., A. El. Nasrat and M. Gamal, 2013. Estrous activity detection device in mammals. Frontiers in Bioscience E5: 798-808.

Scaramuzzi R. J., N. R. Campbell, J. A. Downing, N. R. Kendall, M. Khalid, M. Mun oz-Gutierrez and A. Somchit 2006. A review of the effects of supplementary nutrition in the ewe on the concentrations of reproductive and metabolic hormones and the mechanisms that regulate folliculogenesis and ovulation rate. Reproduction, Fertility and Development 46:339-354.

Schweigert F. J., 1998. Metabolism of carotenoids in mammals. In: G. Britton, S. Liaaen-Jensen, H. Pfander (eds), Carotenoids: Biosynthesis and Metabolism, Vol. 3. Birkhauser Verlag, Basel, pp. 249-284.

SPSS, 2007. Programming and Data Management, statistical package for social science (SPSS), Fourth Edition.

Suzuki J. and N. Katoh, 1990. A simple and cheap method for measuring serum vitamin $\mathrm{A}$ in cattle using only a spectrophotometer. Japanese Journal of Veterinary Science 52:1281-1283.

\footnotetext{
حقن البيتا_كاروتين له تأثير قوى على شدة الثبق ، فيتامين أ ، هورمون الإستراديول VI بيتا فى حملان الإناث البالغة

أنس احمد العربى امين سالمُ ، ندى انور الثهاوى ` ، إبراهيم عبد الله سليمان؟ ا ـ قسم الإنتاج الحيوانى، كلية الزراعة، جامعة أسبوط، r ـ معهد بحوث الانتاج الحبوانى، الدقى، -جيزة

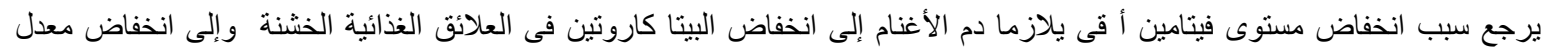

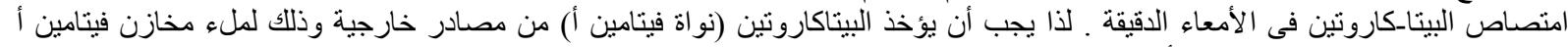

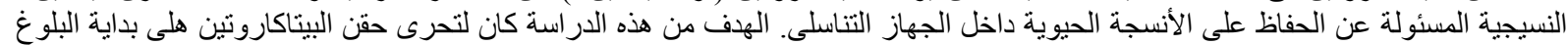

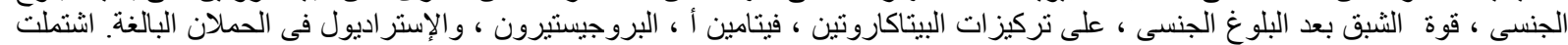

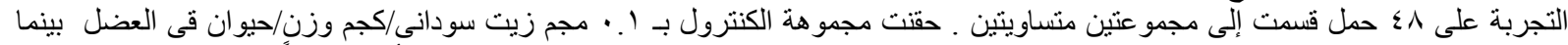

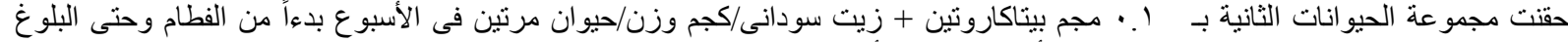

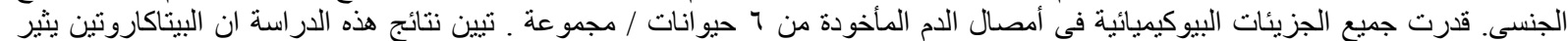

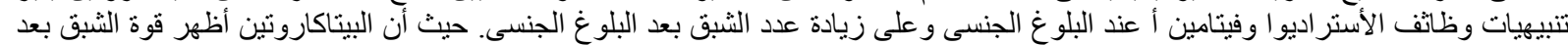

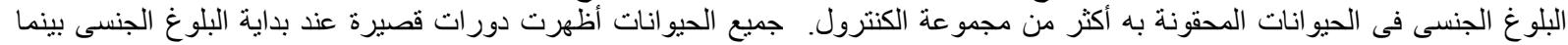

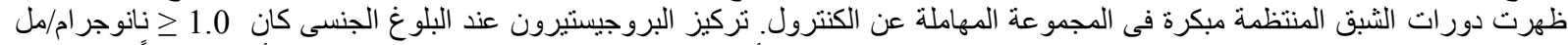

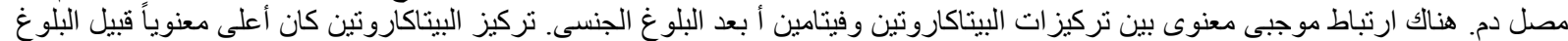

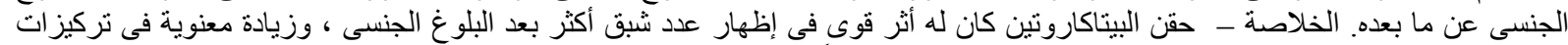

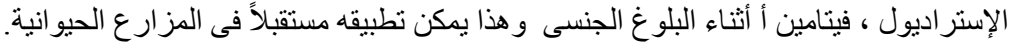

